University of Wollongong

Research Online

Australian Institute for Innovative Materials -

Papers

Australian Institute for Innovative Materials

$1-1-2016$

\title{
Mo02/Mo2C/C spheres as anode materials for lithium ion batteries
}

Mohammad Ihsan

University of Wollongong, mi314@uowmail.edu.au

Hongqiang Wang

University of Wollongong, hw571@uowmail.edu.au

Siti R. Majid

University of Malaya

Jianping Yang

University of Wollongong

Shane J. Kennedy

Australian Nuclear Science And Technology Organisation, sjk@ansto.gov.au

See next page for additional authors

Follow this and additional works at: https://ro.uow.edu.au/aiimpapers

Part of the Engineering Commons, and the Physical Sciences and Mathematics Commons

Research Online is the open access institutional repository for the University of Wollongong. For further information contact the UOW Library: research-pubs@uow.edu.au 


\title{
MoO2/Mo2C/C spheres as anode materials for lithium ion batteries
}

\author{
Abstract \\ $\mathrm{MoO} 2 / \mathrm{Mo} 2 \mathrm{C} / \mathrm{C}$ spheres have been synthesized through hydrothermal and calcination processes. MoO2 is

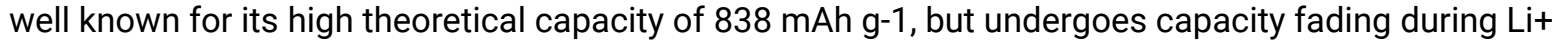 \\ insertion/extraction processes. Mo2C has high specific conductance $(1.02 \times 102 \mathrm{~S} \mathrm{~cm}-1)$ that can provide \\ better electronic conductivity. Carbon is popular for its ability to accommodate the volume variation \\ during charge/discharge. By taking advantage of the combination of $\mathrm{Mo} 2 \mathrm{C}$ and $\mathrm{C}$, these MoO2/Mo2C/C \\ spheres demonstrate not only high cycling performance, but also good rate capability when they are used \\ as anode materials for lithium ion batteries. After 100 cycles at $100 \mathrm{~mA} \mathrm{~g}-1$, the discharge capacities of \\ the $\mathrm{MoO} 2 / \mathrm{Mo} 2 \mathrm{C} / \mathrm{C}$ spheres remain at $800 \mathrm{mAh} \mathrm{g}-1$, suggesting that $\mathrm{MoO} 2 / \mathrm{Mo} 2 \mathrm{C} / \mathrm{C}$ spheres are \\ promising candidates as anode material for lithium ion batteries. \\ Disciplines \\ Engineering | Physical Sciences and Mathematics \\ Publication Details \\ Ihsan, M., Wang, H., Majid, S. R., Yang, J., Kennedy, S. J., Guo, Z. \& Liu, H. Kun. (2016). MoO2/Mo2C/C \\ spheres as anode materials for lithium ion batteries. Carbon, 96 1200-1207. \\ Authors \\ Mohammad Ihsan, Hongqiang Wang, Siti R. Majid, Jianping Yang, Shane J. Kennedy, Zaiping Guo, and \\ Hua-Kun Liu
}

This journal article is available at Research Online: https://ro.uow.edu.au/aiimpapers/2107 


\title{
$\mathrm{MoO}_{2} / \mathrm{Mo}_{2} \mathrm{C} / \mathrm{C}$ Spheres as Anode Materials for Lithium Ion Batteries
}

\author{
Mohammad Ihsan ${ }^{\mathrm{a}, \mathrm{b}, 1}$, Hongqiang Wang ${ }^{\mathrm{a}, 1}$, Siti R. Majid ${ }^{\mathrm{c}}$, Jianping Yang ${ }^{\mathrm{a}}$, Shane J. \\ Kennedy ${ }^{\mathrm{d}}$, Zaiping Guo ${ }^{\mathrm{a}, \mathrm{e}^{* *}}$, and Hua Kun Liu* ${ }^{\mathrm{a}}$
}

a Institute for Superconducting and Electronic Materials, University of Wollongong, NSW 2522, Australia

b PSTBM - BATAN, Kawasan PUSPIPTEK Serpong, Tangerang Selatan, Banten 15314 Indonesia

${ }^{c}$ Centre for Ionics, University of Malaya (CIUM), Department of Physics, Faculty of Science, University of Malaya, 50603 Kuala Lumpur, Malaysia

${ }^{d}$ Bragg Institute, Australian Nuclear Science and Technology Organization, Lucas Heights, NSW 2234, Australia

${ }^{e}$ School of Mechanical, Materials and Mechatronic Engineering, University of Wollongong, NSW 2500, Australia

*Corresponding author. Tel:+61 242214547 Fax:+61 24221 5731. Email address: hua_liu@uow.edu.au; hua@uow.edu.au

** Corresponding author. Tel:+61 242211490 Fax:+61 24221 5731. Email address:

zguo@uow.edu.au

${ }^{1}$ M. Ihsan and H.Q. Wang made equal contributions.

\begin{abstract}
$\mathrm{MoO}_{2} / \mathrm{Mo}_{2} \mathrm{C} / \mathrm{C}$ spheres have been synthesized through hydrothermal and calcination processes. $\mathrm{MoO}_{2}$ is well known for its high theoretical capacity of $838 \mathrm{mAh} \mathrm{g}^{-1}$, but undergoes capacity fading during $\mathrm{Li}^{+}$insertion/extraction processes. $\mathrm{Mo}_{2} \mathrm{C}$ has high specific conductance $\left(1.02 \times 10^{2} \mathrm{~S} \mathrm{~cm}^{-1}\right)$ that can provide better electronic conductivity. Carbon is popular for its ability to accommodate the volume variation during charge/discharge. By taking advantage of the combination of $\mathrm{Mo}_{2} \mathrm{C}$ and $\mathrm{C}$, these $\mathrm{MoO}_{2} / \mathrm{Mo}_{2} \mathrm{C} / \mathrm{C}$ spheres demonstrate not only high cycling performance, but also good rate capability when they are used as anode materials for lithium ion batteries. After 100 cycles at $100 \mathrm{~mA} \mathrm{~g}^{-1}$, the discharge capacities of the $\mathrm{MoO}_{2} / \mathrm{Mo}_{2} \mathrm{C} / \mathrm{C}$ spheres remain at $800 \mathrm{mAh} \mathrm{g}{ }^{-1}$, suggesting that $\mathrm{MoO}_{2} / \mathrm{Mo}_{2} \mathrm{C} / \mathrm{C}$ spheres are promising candidates as anode material for lithium ion batteries.
\end{abstract}

\section{Introduction}

To date, transition metal oxides, such as iron oxide, nickel oxide, and cobalt oxide, have been widely studied as candidate anode materials for lithium ion batteries (LIBs) due to their ability to react with more than two $\mathrm{Li}^{+}$ions per formula unit, resulting in higher capacity than that of graphite [1-6]. Molybdenum dioxide $\left(\mathrm{MoO}_{2}\right)$, one of the transition metal oxides, is remarkably attractive as a host material for lithium ion storage. Its rich chemistry associated with many valence states, low cost, low electrical resistivity, and great 
electrochemical activity towards lithium are the ideal properties for LIB application [7-9]. In terms of capacity, $\mathrm{MoO}_{2}$ has a high theoretical capacity of $838 \mathrm{mAh} \mathrm{g}^{-1}$, due to its ability to accommodate 4 lithium ions per formula unit [10].

In spite of its advantageous properties, $\mathrm{MoO}_{2}$ suffers from two drawbacks. Firstly, the redox conversion process of bulk $\mathrm{MoO}_{2}$ is extremely limited due to the sluggish kinetics of lithium ion insertion $[11,12]$. Secondly, large volume variations take place in the $\mathrm{Li}^{+}$ insertion/extraction processes, leading to electrical pathway damage, disintegration of the active material from the current collector, and serious capacity fading [7, 8, 11, 13-16].

Nanostructuring and fabricating $\mathrm{MoO}_{2}$-carbon composites have been considered in order to enhance the cycling performance of $\mathrm{MoO}_{2}$ electrode. Nanostructuring can maximize the contact surface area between the electrode and electrolyte, so that the diffusion paths for electrons and lithium ions become shorter, resulting in high capacity and rate performance. The nanostructured material still suffers, however, from volume change during lithiation / delithiation.

The other strategy, forming a carbon composite, has demonstrated its ability to improve the performance of $\mathrm{MoO}_{2}$ electrode [7, 17-20]. Carbon acts not only to prevent exfoliation of the active material, but also to improve the conductivity of $\mathrm{MoO}_{2}$, resulting in the enhancement of charge-discharge reversibility and cycling performance. $\mathrm{MoO}_{2}$ /graphene oxide (GO) composite delivered a capacity of $720 \mathrm{mAh} \mathrm{g}^{-1}$ and $560 \mathrm{mAh} \mathrm{g}^{-1}$ after 30 cycles at a current density of $100 \mathrm{~mA} \mathrm{~g}^{-1}$ and $800 \mathrm{~mA} \mathrm{~g}^{-1}$, respectively [10]. $\mathrm{MoO}_{2}-$ ordered mesoporous carbon could maintain a capacity as high as $689 \mathrm{~mA} \mathrm{~h} \mathrm{~g}^{-1}$ after 50 cycles at 50 $\mathrm{mA} \mathrm{g}^{-1}[21]$. $\mathrm{MoO}_{2}-\mathrm{C}$ spheres exhibited good cycling performance and delivered a discharge capacity of $812 \mathrm{mAh} \mathrm{g}^{-1}$ when cycled at $0.2 \mathrm{~A} \mathrm{~g}^{-1}$ [9]. $\mathrm{MoO}_{2}-$ carbon hybrid nanowires delivered a capacity of $327 \mathrm{mAh} \mathrm{g}^{-1}$ at a current density of $1 \mathrm{~A} \mathrm{~g}^{-1}$ after 20 cycles [22]. 
Recently, a new approach to modifying $\mathrm{MoO}_{2}$ material was studied by Zhang et al [23]. They used $\mathrm{Mo}_{2} \mathrm{C}$ to improve the performance of the $\mathrm{MoO}_{2}$ by taking advantage of its high specific conductance $\left(1.02 \times 10^{2} \mathrm{~S} \mathrm{~cm}^{-1}\right)$ and electrochemical inactivity. The high specific conductance of $\mathrm{Mo}_{2} \mathrm{C}$ minimizes the charge transport resistance, leading to better electronic conductivity, and the electrochemical inactivity improves structural stability [24, 25]. Moreover, Gao et al. synthesized $\mathrm{Mo}_{2} \mathrm{C}-\mathrm{C}$ hybrid nanospheres through solvothermal synthesis and a reduction-carbonization method, and they demonstrated capacity of 672.7 $\mathrm{mAh} \mathrm{g}^{-1}$ after 50 cycles at a current density of $100 \mathrm{~mA} \mathrm{~g}^{-1}[26]$.

In this work, we have combined the advantages of both $\mathrm{Mo}_{2} \mathrm{C}$ and $\mathrm{C}$ in order to improve the performance of $\mathrm{MoO}_{2}$ by preparing $\mathrm{MoO}_{2} / \mathrm{Mo}_{2} \mathrm{C} / \mathrm{C}$ spheres as anode material for lithium ion batteries by the hydrothermal method followed by calcination. The as-prepared $\mathrm{MoO}_{2} / \mathrm{Mo}_{2} \mathrm{C} / \mathrm{C}$ spheres have demonstrated not only high cycling performance, with capacity of $800 \mathrm{mAh} \mathrm{g}^{-1}$ after 100 cycles, but also good rate capability. The excellent electrochemical performance can be ascribed to the synergetic effects of $\mathrm{Mo}_{2} \mathrm{C}$, carbon, and $\mathrm{MoO}_{2}$ in the composite anode material.

\section{Experimental}

\subsection{Preparation of Materials}

First, the resol precursor was made by mixing and stirring $0.6 \mathrm{~g}$ phenol, $2.1 \mathrm{ml}$ formalin aqueous solution (37 wt \%) and $15 \mathrm{ml} \mathrm{NaOH}$ aqueous solution $(0.1 \mathrm{M})$ at $70{ }^{\circ} \mathrm{C}$ for 0.5 h. After that, $0.96 \mathrm{~g}$ Pluronic F127 triblock copolymer (Sigma Aldrich) dissolved in $15 \mathrm{ml}$ $\mathrm{H}_{2} \mathrm{O}$ was added. Then, the stirring was continued for $2 \mathrm{~h}$ at $66^{\circ} \mathrm{C}$. After that, $50 \mathrm{ml}$ water was added to dilute the solution, and stirring was continued for $18 \mathrm{~h}$. The obtained solution was named as Pluronic F127 - resol mixture solution. Afterwards, $17 \mathrm{ml}$ of the obtained solution, $10 \mathrm{~mL}$ ethylene glycol, $\mathrm{X}$ mmol $(\mathrm{X}=0.5,0.25)$ ammonium heptamolybdate tetrahydrate 
(AHM), and $41 \mathrm{ml} \mathrm{H}_{2} \mathrm{O}$ were mixed and stirred for $1 \mathrm{~h}$. The solution was moved into an autoclave and heated at $180{ }^{\circ} \mathrm{C}$ for $24 \mathrm{~h}$. The obtained products were collected by centrifuge, washed with deionized water and ethanol, and dried at room temperature. The sample was further annealed at $700{ }^{\circ} \mathrm{C}$ for $4 \mathrm{~h}$ in nitrogen atmosphere with a heating rate of $2{ }^{\circ} \mathrm{C} / \mathrm{min}$. The resultant samples obtained from 0.5 and $0.25 \mathrm{mmol}\left(\mathrm{NH}_{4}\right)_{6} \mathrm{Mo}_{7} \mathrm{O}_{24} \cdot 4 \mathrm{H}_{2} \mathrm{O}$ were denoted as MMC-050 and MMC-025, respectively. For comparison purposes, molybdenum dioxide nanoparticles were prepared by the same procedure as MMC-050 and MMC-025 without using Pluronic F127 -resol mixture solution (denoted as $\mathrm{MoO}_{2} \mathrm{np}$ ).

\subsection{Material Characterisation}

The crystal structure of the materials was characterised by X-ray diffraction (XRD;GBC MMA Diffractometer, $\mathrm{Cu} \mathrm{K} \alpha$ radiation, $\lambda=1.5406 \AA$ ) and small-angle $\mathrm{X}$-ray scattering (SAXS) with a Nanostar U small-angle X-ray scattering system (Bruker, Germany) using $\mathrm{Cu} \mathrm{K} \alpha$ radiation. The dimensions and morphology were examined using field emission scanning electron microscopy (FE-SEM; JEOL JSM-7500) and transmission electron microscopy (TEM; JEOL 2011). Thermogravimetric analysis (TGA; Mettler Toledo TGA/DSC1) was used to determine the carbon content. The specific surface area was measured using the Brunauer-Emmett-Teller (BET) method.

For electrochemical performance testing, working electrodes were prepared by mixing $85 \mathrm{wt} \%$ sample as the active material, $6 \mathrm{wt} \%$ conductive agent (carbon black, Super-P-Li), and $9 \mathrm{wt} \%$ polyvinylidene difluoride (PVDF) binder, and the resultant slurry was pasted uniformly onto copper foil. The as-prepared working electrodes were then dried in a vacuum oven at $120^{\circ} \mathrm{C}$ for 12 hours. Electrochemical cells (CR2032 coin type) were assembled in an Ar-filled glove box (Mbraun, Unilab, USA) by using the working electrode, a separator (polypropylene film), Li foil as the reference and counter electrode, and $1 \mathrm{M} \mathrm{LiPF}_{6}$ in a 1:1 (v/v) mixture of ethylene carbonate (EC) and diethyl carbonate (DEC) as the electrolyte. The 
cells were galvanostatically charged and discharged over the voltage range of $0.01-3 \mathrm{~V}$ versus $\mathrm{Li} / \mathrm{Li}^{+}$at different constant current densities, based on the weight of the sample, on a Land CT2001A cycler.

\section{Results and discussion}

A schematic illustration of the fabrication of the $\mathrm{MoO}_{2} / \mathrm{Mo}_{2} \mathrm{C} /$ carbon spheres is presented in Figure 1. Resol-F127 composite is produced by the interaction between the resol precursor and the triblock copolymer Pluronic F127 under stirring at a temperature of $66^{\circ} \mathrm{C}$ for $18 \mathrm{~h}$. After that, the composite interacts with AHM and ethylene glycol under the hydrothermal process at $180{ }^{\circ} \mathrm{C}$ for $24 \mathrm{~h}$. In this process, the $\mathrm{MoO}_{2} /$ resin sphere precursor is formed. The $\mathrm{MoO}_{2}$ is a product of the reduction of AHM with ethylene glycol. The calcination process at a temperature of $700{ }^{\circ} \mathrm{C}$ in $\mathrm{N}_{2}$ leads to the formation of porous spheres of carbon and $\mathrm{MoO}_{2}$. Further reaction of the $\mathrm{MoO}_{2}$ and the carbon generates $\mathrm{Mo}_{2} \mathrm{C}$, resulting in the $\mathrm{MoO}_{2} / \mathrm{Mo}_{2} \mathrm{C} /$ carbon spheres.

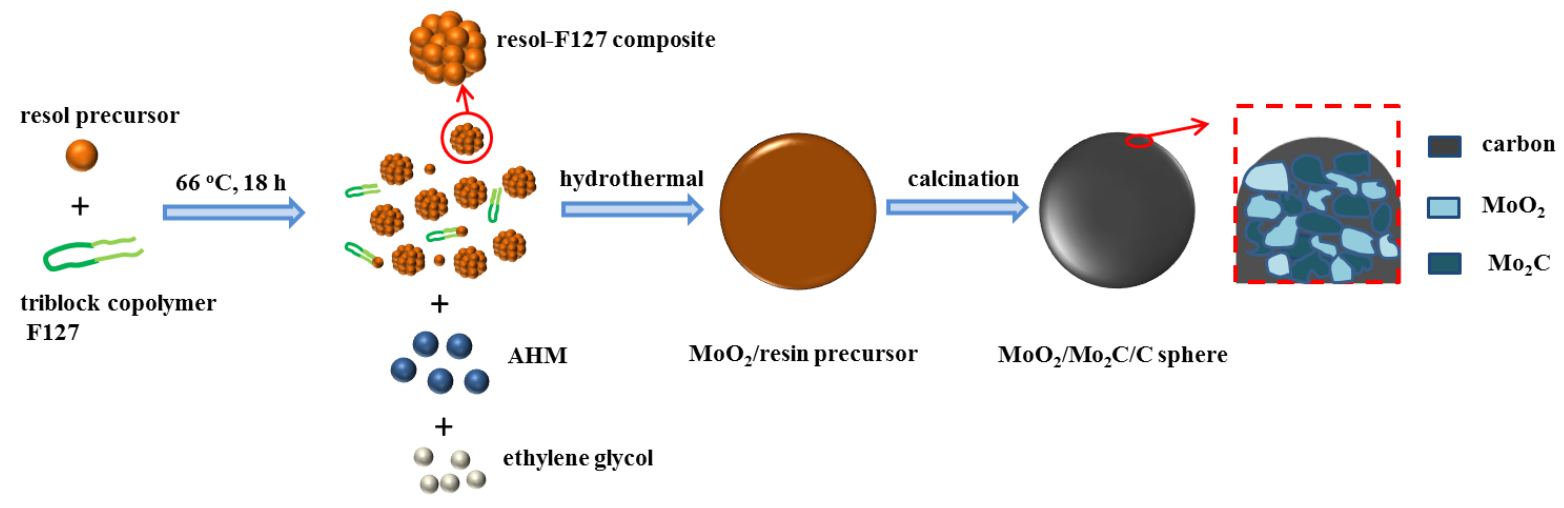

Figure 1. Schematic illustration of the preparation of the $\mathrm{MoO}_{2} / \mathrm{Mo}_{2} \mathrm{C} /$ carbon spheres.

XRD patterns of the $\mathrm{MoO}_{2} / \mathrm{Mo}_{2} \mathrm{C} /$ carbon sphere composites and $\mathrm{MoO}_{2}$ nanoparticles are shown in Figure 2(a). The patterns show a combination of peaks belonging to $\mathrm{MoO}_{2}$ and to $\mathrm{Mo}_{2} \mathrm{C}$ in both the MMC-050 and the MMC-025 samples. The diffraction patterns can be 
indexed to monoclinic $\mathrm{MoO}_{2}$ with space group P2 1 /c (JCPDS 78-1071) and orthorhombic $\mathrm{Mo}_{2} \mathrm{C}$ with space group Pca21 (JCPDS 77-0720). The diffraction peaks located at $25.9^{\circ}$, $36.9^{\circ}, 53^{\circ}$, and $53.3^{\circ}$ belong to the (011), (200), (-312), and (022) planes of $\mathrm{MoO}_{2}$, respectively. The peaks located at $34.5^{\circ}, 39.5^{\circ}, 61.7^{\circ}, 69.7^{\circ}$, and $74.6^{\circ}$ are assigned to the molybdenum carbide $\left(\mathrm{Mo}_{2} \mathrm{C}\right)$. No diffraction peaks corresponding to other Mo species were observed, suggesting that all of the AHM was transformed into $\mathrm{MoO}_{2}$ and $\mathrm{Mo}_{2} \mathrm{C}$ species. Table 1 lists the compositions of MMC-050 and MMC-025 from thermogravimetric analysis (TGA) data in Figure S1 (Supporting Information) and Match software analysis.
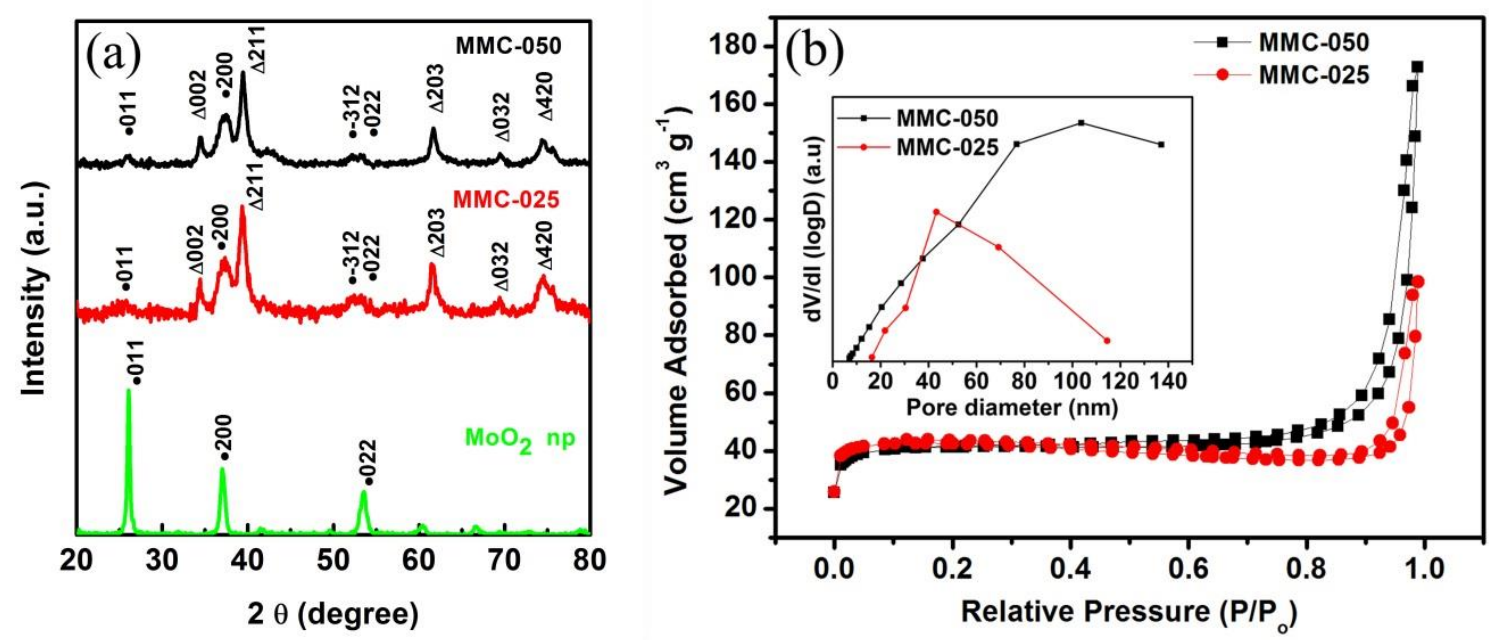

Figure 2. (a) XRD patterns of MMC-050, MMC-025, and $\mathrm{MoO}_{2}$ nanoparticles. Peaks marked with the symbols $\bullet$ and $\nabla$ correspond to $\mathrm{MoO}_{2}$ and $\mathrm{Mo}_{2} \mathrm{C}$, respectively; (b) nitrogen adsorption-desorption isotherms of MMC-050 and MMC-025 (inset: pore size distribution curves of MMC-050 and MMC-025).

Table 1. Content of $\mathrm{C}, \mathrm{MoO}_{2}$, and $\mathrm{Mo}_{2} \mathrm{C}$ species in the samples in weight percent.

\begin{tabular}{rccc}
\hline \multicolumn{1}{c}{ Sample } & $\boldsymbol{C}(\%)$ & $\mathrm{MoO}_{2}(\%)$ & $\mathrm{Mo}_{2} \mathrm{C}(\%)$ \\
\hline MMC-050 & 10 & 35.1 & 54.9 \\
MMC-025 & 20 & 23.84 & 56.16 \\
\hline
\end{tabular}


Nitrogen adsorption-desorption isotherms of the MMC-050 and MMC-025 are presented in Figure 2(b). The Figure shows type IV curves according to the IUPAC classification, suggesting mesoporous material, and it displays typical H1 hysteresis loops, which are usually found in spherical structures. The mesostructure has been confirmed by SAXS analysis. The SAXS patterns of MMC-050 and MMC-025 in Figure S2 in the Supporting Information show no peaks, indicating disordered mesostructure. The pore distribution curves (inset in Fig. 2(b)) reveal that MMC-050 and MMC-025 have both mesoporous and macroporous structure. The disorderd mesoporous and macroporous structure could be generated from the phase separation process of F127 micelle after surfactant removal during self-assembly process. MMC-050 and MMC-025 have BET surface areas of $154.3 \mathrm{~m}^{2} \mathrm{~g}^{-1}$ and $159.6 \mathrm{~m}^{2} \mathrm{~g}^{-1}$, respectively. The total pore volume of MMC050 is $0.26 \mathrm{~cm}^{3} \mathrm{~g}^{-1}$, while MMC- 025 has a total pore volume of $0.15 \mathrm{~cm}^{3} \mathrm{~g}^{-1}$.

The morphological and textural details of the samples were revealed by SEM and TEM. Figure 3 displays SEM images of the MMC-050 and MMC-025 samples, while an SEM image of the $\mathrm{MoO}_{2}$ nanoparticles can be seen in Figure S3 (Supporting Information). Figures 3(a-d) gives the general morphology of the MMC-050 and MMC-025 samples. As can be seen in Figure 3(b, d), the size distribution ranges of the MMC-050 and the MMC-025 spheres are between 2-3 and 1-3 $\mu \mathrm{m}$, respectively. The surface appearance of MMC-025 is smoother than that of MMC-050. The smoother appearance of MMC-025 may be due to the use of a lower concentration of precursor, leading to the presence of a smaller amount of Mo species compared to MMC-050. In order to see the distribution of Mo species $\left(\mathrm{MoO}_{2}\right.$ and $\mathrm{Mo}_{2} \mathrm{C}$ ), energy dispersive X-ray spectroscopy (EDS) mapping was performed on MMC-025, as shown in Figure 3(e-g), which confirms that the molybdenum and carbon are uniformly distributed in the carbon spheres. Figure 4 presents the SEM images of MMC-025 and MMC050 samples after cycling performance test. It can be seen that both of MMC-025 and MMC- 
050 can maintain their spheres form after cycling performance test showing the stability of the structure.

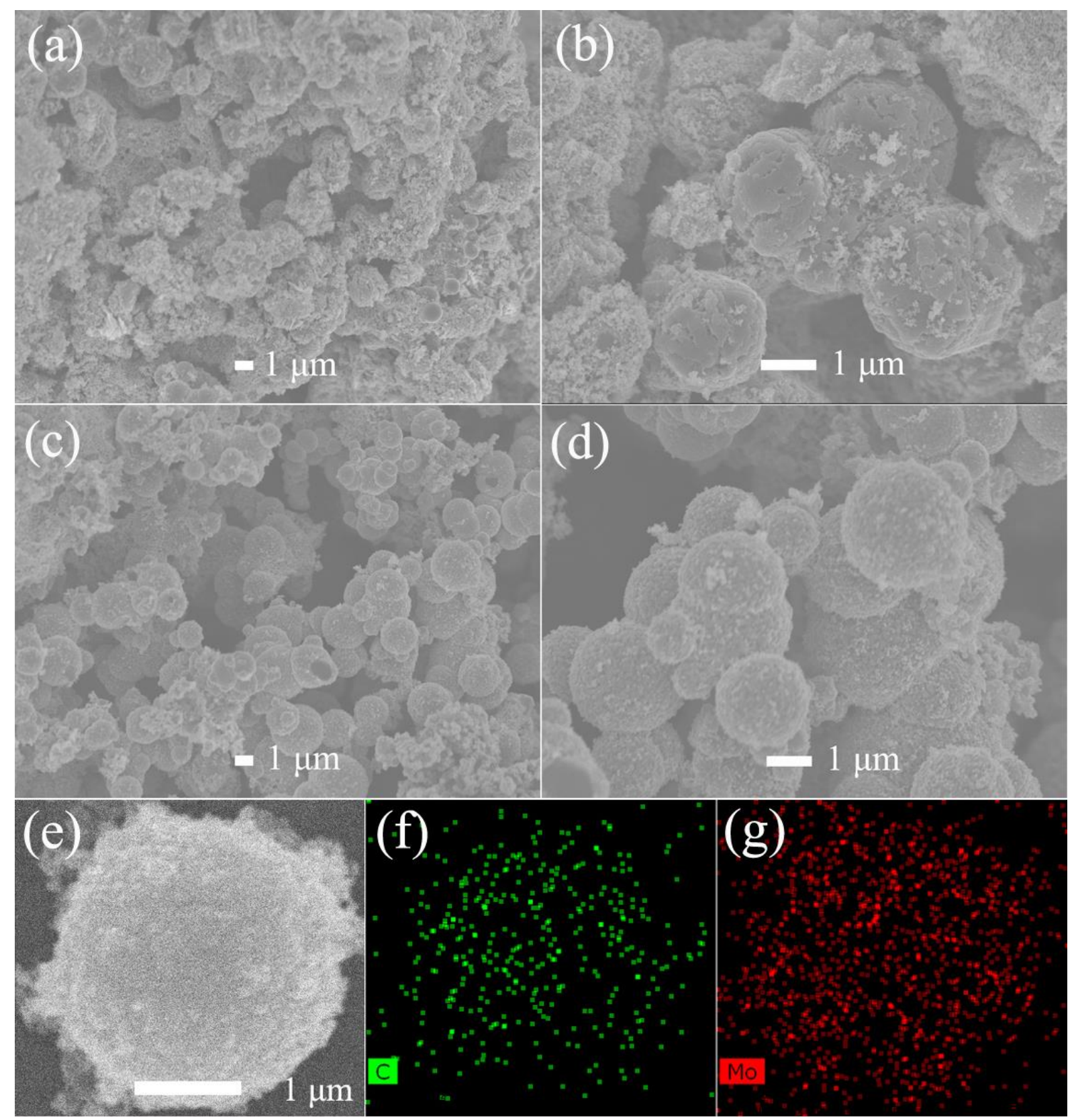

Figure 3. (a) SEM image of MMC-050 at lower magnification and (b) at higher magnification; (c) SEM image of MMC-025 at lower magnification and (d) at higher magnification; (e) SEM image and (f-g) corresponding EDS mapping of MMC-025. 


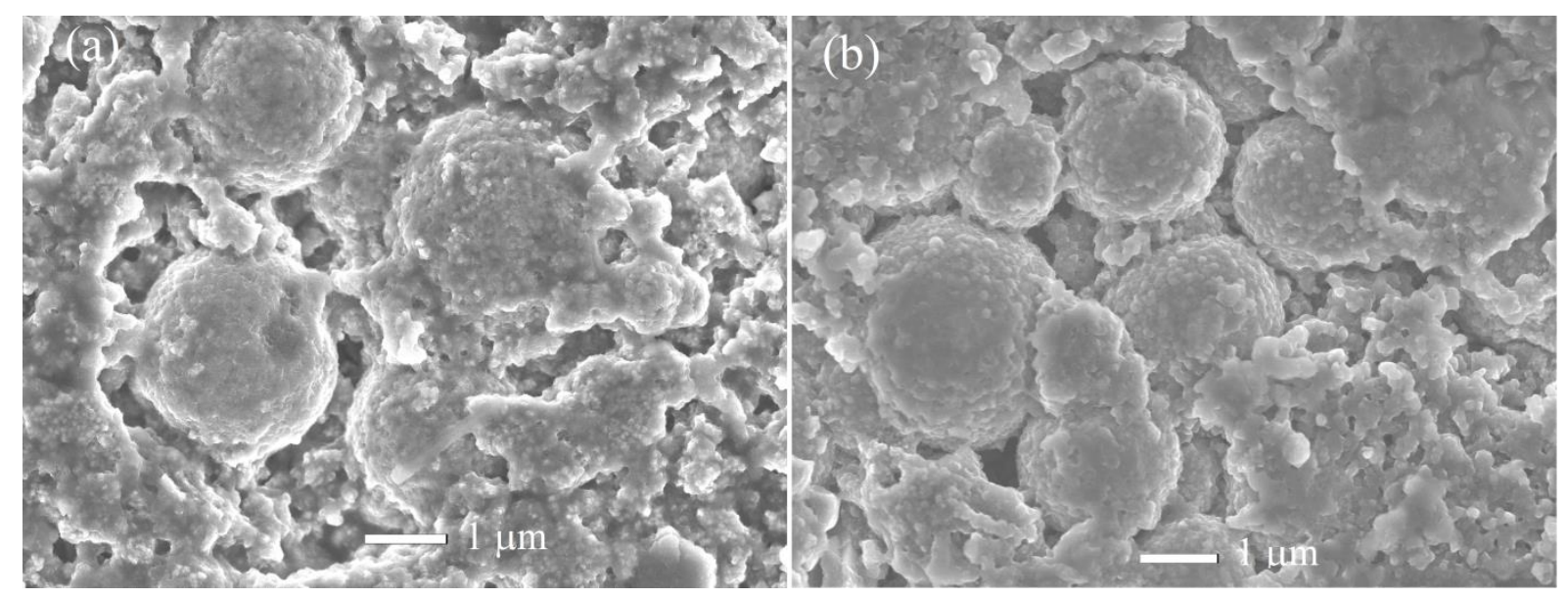

Figure 4. SEM images after cycling performance test of: (a) MMC-025; and (b) MMC-050.

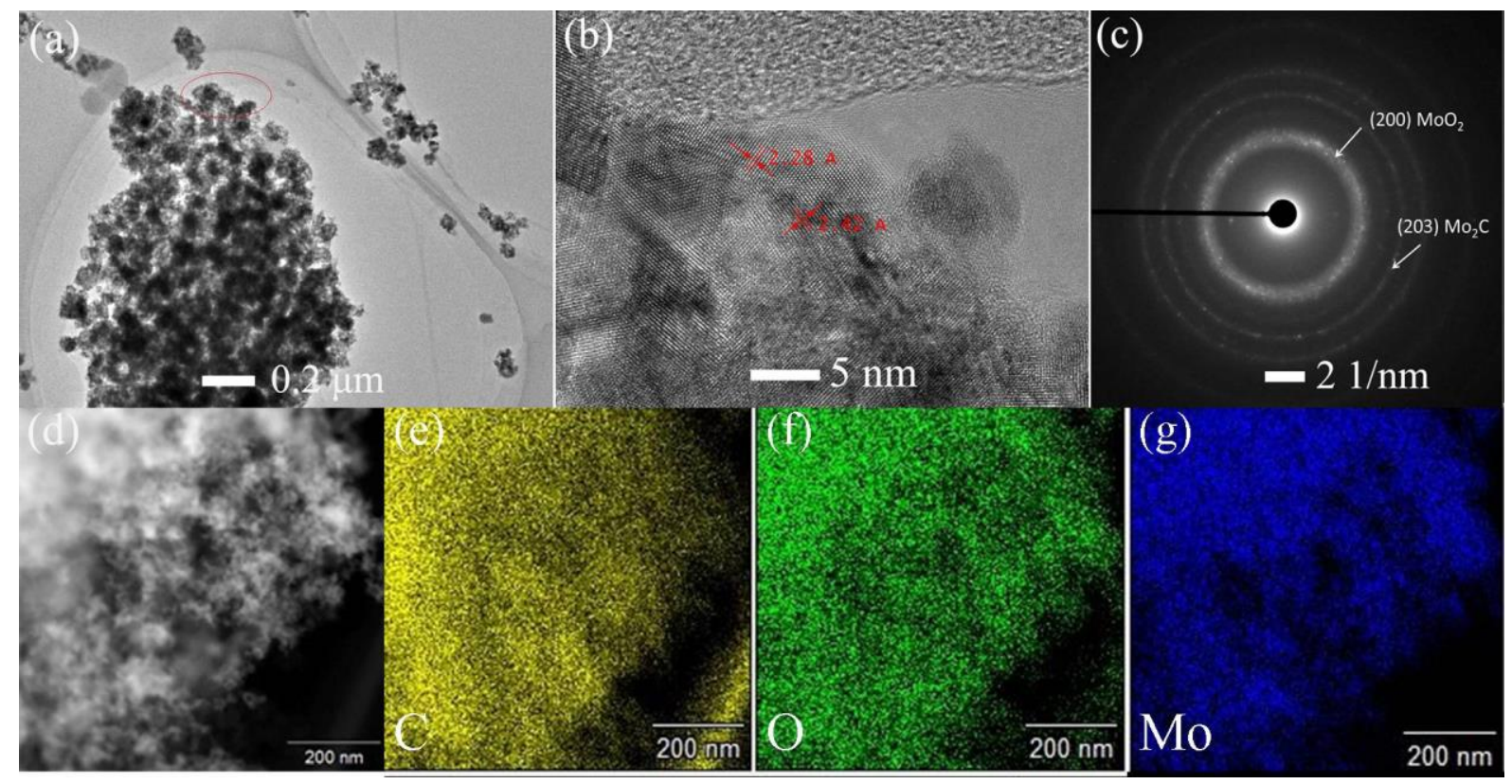

Figure 5. (a) TEM image of MMC-025 sphere at low resolution; (b) higher magnification TEM image of the selected area of MMC-025 in (a); (c) SAED pattern of (a); (d-g) EDS mapping of selected area in (a).

TEM and high resolution TEM (HR-TEM) images of the MMC-025 sphere composite are shown in Figure 5. Figure 5(a) shows the appearance of a sphere at low resolution. The positions of $\mathrm{MoO}_{2}$ and $\mathrm{Mo}_{2} \mathrm{C}$ in the spheres cannot be identified clearly because they overlap with each other, as confirmed by EDS mapping in Fig. 5(e-g). An HRTEM image of the sample is displayed in Figure 5(b). The HRTEM observations demonstrate that the spheres 
are composed of both $\mathrm{MoO}_{2}$ and $\mathrm{Mo}_{2} \mathrm{C}$ nanoparticles. The 2.28 and $2.42 \AA$ lattice fringes are associated with the (211) planes of $\mathrm{Mo}_{2} \mathrm{C}$ and the (200) planes of $\mathrm{MoO}_{2}$, respectively. The results are in good agreement with the XRD analysis. The corresponding selected area electron diffraction (SAED) pattern is shown in Fig. 5(c), where the rings can be indexed to monoclinic $\mathrm{MoO}_{2}$ and orthorhombic $\mathrm{Mo}_{2} \mathrm{C}$, which are also consistent with the XRD results.

Representative charge-discharge profiles of MMC-050 at a current density of $100 \mathrm{~mA}$ $\mathrm{g}^{-1}$ in a voltage window of $0.01-3 \mathrm{~V}$ are shown in Figure 6(a). The first discharge and charge capacities of the $\mathrm{MoO}_{2} / \mathrm{Mo}_{2} \mathrm{C} /$ carbon spheres are approximately 1172 and $790.3 \mathrm{mAh}$ $\mathrm{g}^{-1}$, respectively, calculated based on the total weight of the composite material. The corresponding coulombic efficiency is $67.4 \%$ for the first cycle. The capacity loss in the first cycle is attributed to irreversible processes affected by three factors: the trapping of some lithium ions in the $\mathrm{MoO}_{2}$ lattice, the formation of a solid electrolyte interphase (SEI) layer, and electrolyte molecule decomposition. No significant capacity fading is observed in the following $2^{\text {nd }}, 20^{\text {th }}$, and $50^{\text {th }}$ cycles. The appearance of $\mathrm{Mo}_{2} \mathrm{C}$ and $\mathrm{C}$ in the composite spheres can increase the structural stability and buffer the volume changes during insertion/extraction of lithium ions as well, and as a result, there is no serious capacity fading after 50 cycles.

The cycling performances of MMC-050, MMC-025, and $\mathrm{MoO}_{2}$ nanoparticles at a current density of $100 \mathrm{~mA} \mathrm{~g}^{-1}$ over a voltage range of $0.01-3 \mathrm{~V}$ are displayed in Figure 6(b). Both samples of $\mathrm{MoO}_{2} / \mathrm{Mo}_{2} \mathrm{C} /$ carbon spheres (MMC-050 and MMC-025) show not only improved discharge capacities compared to the $\mathrm{MoO}_{2}$ nanoparticles, but also show higher discharge capacities than their theoretical capacities, which are 466.39 and $412.33 \mathrm{mAh} \mathrm{g}^{-1}$ for MMC-050 and MMC-025, respectively (details are available in the Supporting Information). When those $\mathrm{MoO}_{2} / \mathrm{Mo}_{2} \mathrm{C} /$ carbon spheres are charged and discharged, the discharge capacities are fairly stable for the first 20 cycles. These stable discharge capacities are better than those of $\mathrm{MoO}_{2} /$ carbon spheres and $\mathrm{MoO}_{2} / \mathrm{Mo}_{2} \mathrm{C}$ heteronanotubes, which 
undergo significant capacity fading in the initial cycles [9, 23]. The stable discharge capacities of the $\mathrm{MoO}_{2} / \mathrm{Mo}_{2} \mathrm{C} /$ carbon spheres indicate that the combination of $\mathrm{Mo}_{2} \mathrm{C}$ and $\mathrm{C}$ in the spheres has significant advantages for the cycling performance of $\mathrm{MoO}_{2}$ by preventing the capacity from declining in the initial cycles. More importantly, the discharge capacities of MMC-050 and MMC-025 are well maintained around $800 \mathrm{mAh} \mathrm{g}^{-1}$ after 100 cycles. The cycling performance of the $\mathrm{MoO}_{2} / \mathrm{Mo}_{2} \mathrm{C} / \mathrm{C}$ electrodes is also significantly higher than that of the $\mathrm{MoO}_{2}$ nanoparticles. The superior cycling performance of the $\mathrm{MoO}_{2} / \mathrm{Mo}_{2} \mathrm{C} /$ carbon spheres can be attributed to its structure and configuration, consisting of porous spheres, the good electrical conductivity of carbon and $\mathrm{Mo}_{2} \mathrm{C}$ in the composite, the buffering effect of carbon, which accommodates and alleviates the volume changes of $\mathrm{MoO}_{2}$ during cycling and the structural stability of $\mathrm{Mo}_{2} \mathrm{C}[9,22,23,26-36]$. It can be proved by comparing cycling performance data of $\mathrm{MoO}_{2} \mathrm{np}$ and MMC-050 with $54.9 \%$ of $\mathrm{Mo}_{2} \mathrm{C}$ and $10 \%$ of $\mathrm{C}$ that $\mathrm{Mo}_{2} \mathrm{C}$ and carbon in MMC-050 can prevent the capacity fading that occurs in $\mathrm{MoO}_{2} \mathrm{np}$ during the cycling process. Moreover, the more content of $\mathrm{Mo}_{2} \mathrm{C}$ and $\mathrm{C}(56.16 \%$ and $20 \%)$ in MMC-025 compare to that of MMC-050 (54.9\% and $10 \%)$ lead to the increased capacity during the cycling. $\mathrm{MoO}_{2}, \mathrm{Mo}_{2} \mathrm{C}$, and carbon work simultaneously and synergistically, resulting in the superior cycling performance of the $\mathrm{MoO}_{2} / \mathrm{Mo}_{2} \mathrm{C} /$ carbon spheres.

The discharge capacities of MMC-050 and MMC-025 are comparable to the discharge capacities of reported $\mathrm{MoO}_{2}, \mathrm{MoO}_{2} / \mathrm{Mo}_{2} \mathrm{C}$ hybrid, and $\mathrm{MoO}_{2} /$ carbon composite, as shown in Table $2[9,23,26,37,38]$. The cycling performances of the present $\mathrm{MoO}_{2} / \mathrm{Mo}_{2} \mathrm{C} /$ carbon sphere and $\mathrm{MoO}_{2}$ nanoparticle electrodes have also been studied at higher current density (500 $\mathrm{mA} \mathrm{g}^{-1}$ ), as shown in Figure 6(c). The cells delivered 650 and 550 $\mathrm{mAh} \mathrm{g}^{-1}$ of discharge capacities after 100 cycles for MMC-050 and MMC-025, respectively, and showed better performance than the cells containing $\mathrm{MoO}_{2}$ nanoparticles. 

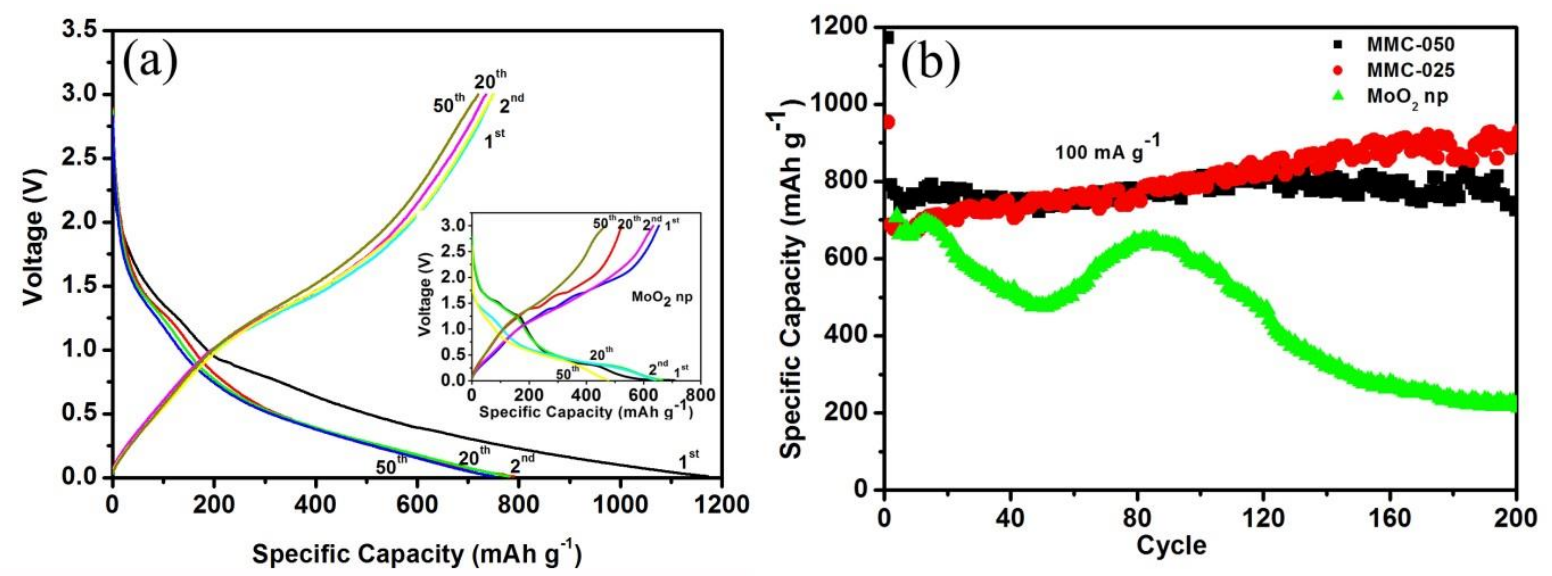

(c)
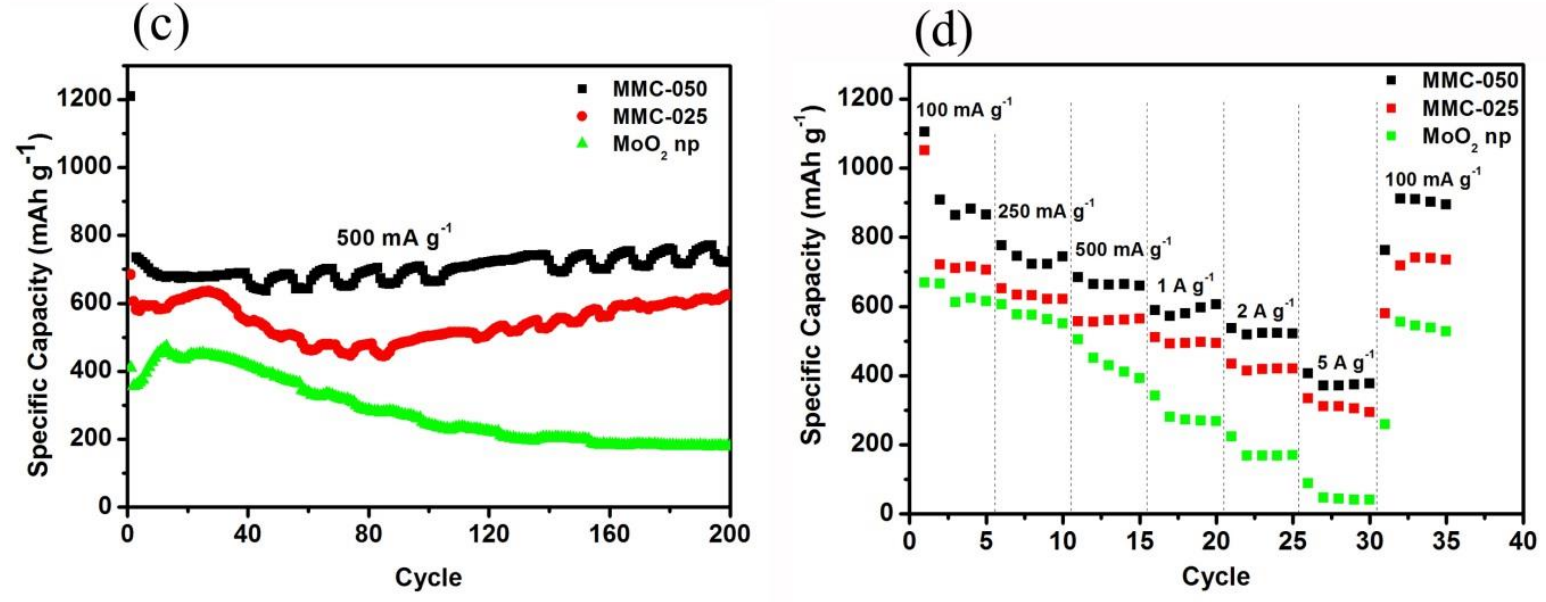

Figure 6. (a) Charge/discharge voltage profiles of MMC-050 at the current density of 100 $\mathrm{mA} \mathrm{g}^{-1}$ for the selected cycles indicated (inset: charge/discharge profiles of $\mathrm{MoO}_{2}$ nanoparticles); (b) cycling performances of MMC-050, MMC-025, and $\mathrm{MoO}_{2} \mathrm{np}$ in the voltage range of $0.01-3 \mathrm{~V}$ at the current density of $100 \mathrm{~mA} \mathrm{~g}^{-1}$; (c) cycling performances of MMC-050, MMC-02, and $\mathrm{MoO}_{2} \mathrm{np}$ at higher current density $\left(500 \mathrm{~mA} \mathrm{~g}^{-1}\right)$; (d) rate capability of MMC-050, MMC-025, and $\mathrm{MoO}_{2} \mathrm{np}$ at various current densities. (Notes : The discharge capacity is used in the figures 6(a), 6(b), and 6(c)).

The $\mathrm{MoO}_{2} / \mathrm{Mo}_{2} \mathrm{C} /$ carbon sphere samples also exhibit excellent rate capability (Figure 6(d)). The MMC-050 and MMC-025 samples show higher capacities than the $\mathrm{MoO}_{2} \mathrm{np}$ at all current densities. The capacity decrease in the initial cycle of MMC-050 and MMC-025 is related to irreversible processes involving three factors: some lithium ions are trapped in the $\mathrm{MoO}_{2}$ lattice, the formation of a solid electrolyte interphase (SEI) layer, and decomposition of electrolyte molecule. The discharge capacities of MMC-050 are 880, 750, and $680 \mathrm{mAh} \mathrm{g}^{-}$ 1 at current densities of 100,250 , and $500 \mathrm{~mA} \mathrm{~g}^{-1}$, respectively. In contrast, the $\mathrm{MoO}_{2} \mathrm{np}$ shows lower capacities of 600,550 , and $400 \mathrm{mAh} \mathrm{g}^{-1}$ at current densities of 100, 250, and 
$500 \mathrm{~mA} \mathrm{~g}^{-1}$, respectively. The capacities of MMC-050 and MMC-025 remain as high as the initial capacities when the current density is returned to $100 \mathrm{~mA} \mathrm{~g}^{-1}$ after a deep cycling at 5 $\mathrm{A} \mathrm{g}^{-1}$. Our $\mathrm{MoO}_{2} / \mathrm{Mo}_{2} \mathrm{C} / \mathrm{C}$ composite anode materials exhibit better rate capability compared with those of $\mathrm{MoO}_{2} /$ carbon and $\mathrm{Mo}_{2} \mathrm{C} / \mathrm{C}$ composite reported in the literature $[10,21,26,39$, 40]. The superior rate capability of $\mathrm{MoO}_{2} / \mathrm{Mo}_{2} \mathrm{C} /$ carbon spheres can be explained by the following reasons. Firstly, the porous carbon spheres provide short pathways for the transport of electrons and also supply the space for the volume changes of $\mathrm{MoO}_{2}$. Secondly, the good contact of $\mathrm{MoO}_{2}$ nanoparticles, $\mathrm{Mo}_{2} \mathrm{C}$ nanoparticles, and the carbon in the spheres reduces the electrode resistance, thereby facilitating electron movement. The appearance of $\mathrm{Mo}_{2} \mathrm{C}$ also enhances the electronic conductivity of the spheres, generating the good rate capability performance.

Table 2. Comparison of the electrochemical performance of MMC-050 with some published reports on $\mathrm{MoO}_{2}$ and $\mathrm{MoO}_{2} /$ Carbon composites.

\begin{tabular}{|c|c|c|}
\hline $\begin{array}{c}\text { Electrode } \\
\text { Description }\end{array}$ & Rate Capability & $\begin{array}{c}\text { Specific Capacity after } 100 \text { Reference } \\
\text { cycles }\end{array}$ \\
\hline
\end{tabular}

\begin{tabular}{|c|c|c|}
\hline $\begin{array}{l}\text { Hierarchical } \mathrm{MoO}_{2} \\
\text { monolith }\end{array}$ & Not available & $\begin{array}{l}719 \mathrm{mAh} \mathrm{g}^{-1} \text { at } 200 \mathrm{~mA} \mathrm{~g}^{-1} \\
\text { (after } 20 \text { cycles) }\end{array}$ \\
\hline $\mathrm{MoO}_{2} / \mathrm{C}$ & $\begin{array}{l}500 \mathrm{mAh} \mathrm{g}^{-1} \text { at } 400 \mathrm{~mA} \mathrm{~g}^{-1} \\
375 \mathrm{mAh} \mathrm{g}^{-1} \text { at } 1.2 \mathrm{~A} \mathrm{~g}^{-1}\end{array}$ & $500 \mathrm{mAhg}^{-1}$ at $100 \mathrm{~mA} \mathrm{~g}^{-1}$ \\
\hline $\mathrm{MoO}_{2} / \mathrm{C}$ spheres & $\begin{array}{l}350 \mathrm{mAh} \mathrm{g}^{-1} \text { at } 500 \mathrm{~mA} \mathrm{~g}^{-1} \\
300 \mathrm{mAh} \mathrm{g}^{-1} \text { at } 1 \mathrm{~A} \mathrm{~g}^{-1}\end{array}$ & $800 \mathrm{mAh} \mathrm{g}^{-1}$ at $200 \mathrm{~mA} \mathrm{~g}^{-1}$ \\
\hline $\begin{array}{l}\mathrm{MoO}_{2} / \mathrm{Mo}_{2} \mathrm{C} \\
\text { heteronanotubes }\end{array}$ & $\begin{array}{l}500 \mathrm{mAh} \mathrm{g}^{-1} \text { at } 500 \mathrm{~mA} \mathrm{~g}^{-1} \\
400 \mathrm{mAh} \mathrm{g}^{-1} \text { at } 1 \mathrm{~A} \mathrm{~g}^{-1}\end{array}$ & $800 \mathrm{mAh} \mathrm{g}^{-1}$ at $200 \mathrm{~mA} \mathrm{~g}^{-1}$ \\
\hline $\begin{array}{l}\mathrm{Mo}_{2} \mathrm{C} / \mathrm{C} \\
\text { nanospheres }\end{array}$ & $\begin{array}{l}500 \mathrm{mAh} \mathrm{g}^{-1} \text { at } 500 \mathrm{~mA} \mathrm{~g}^{-1} \\
450 \mathrm{mAh} \mathrm{g}^{-1} \text { at } 1 \mathrm{~A} \mathrm{~g}^{-1}\end{array}$ & $\begin{array}{l}673 \mathrm{mAh} \mathrm{g}^{-1} \text { at } 100 \mathrm{~mA} \mathrm{~g}^{-1} \\
\text { (after } 50 \text { cycles) }\end{array}$ \\
\hline $\begin{array}{l}\text { This work } \\
\text { (MMC-050) }\end{array}$ & $\begin{array}{l}700 \mathrm{mAh} \mathrm{g}^{-1} \text { at } 500 \mathrm{~mA}^{-1} \\
600 \mathrm{mAh} \mathrm{g}^{-1} \text { at } 1 \mathrm{~A} \mathrm{~g}^{-1}\end{array}$ & $800 \mathrm{mAh} \mathrm{g}^{-1}$ at $100 \mathrm{~mA} \mathrm{~g}^{-1}$ \\
\hline
\end{tabular}


Cyclic voltammetry (CV) of MMC-025 was conducted to inspect the redox behaviour of the sample during charging-discharging. Figure 7(a) shows a cyclic voltammogram of MMC-025 at a scan rate of $0.1 \mathrm{mV} \mathrm{s}^{-1}$ over the potential range of $0.01-3 \mathrm{~V}$. When the potential is above $1.0 \mathrm{~V}$, the lithium ions are inserted into the $\mathrm{MoO}_{2}$ structure, resulting in $\mathrm{Li}_{x} \mathrm{MoO}_{2}$, and when discharge is lower than $1.0 \mathrm{~V}, \mathrm{Li}_{x} \mathrm{MoO}_{2}$ is gradually transformed into $\mathrm{Li}_{2} \mathrm{O}$ and Mo metal. The first cycle displays an irreversible peak at $0.7 \mathrm{~V}$, which is related to decomposition of electrolyte and solid electrolyte interphase (SEI) formation. Two reduction/oxidation pairs at $1.24 / 1.4 \mathrm{~V}$ and $1.52 / 1.7 \mathrm{~V}$ were observed in the following cycles and are correlated with the reversible phase transitions of partially lithiated $\mathrm{Li}_{x} \mathrm{MoO}_{2}$ during charging/discharging [41]. Meanwhile, two pairs of peaks from $\mathrm{MoO}_{2}$ nanoparticles can be observed at 1.27/1.5 V and 1.52/1.7 V in the inset in Figure 7(a). The CV curves are stable after the second cycle, with all the cycles repeating themselves very well, indicating that the phase transitions are highly reversible and demonstrating the advantages of $\mathrm{Mo}_{2} \mathrm{C}$ and $\mathrm{C}$ for the structural stability of $\mathrm{MoO}_{2}$.
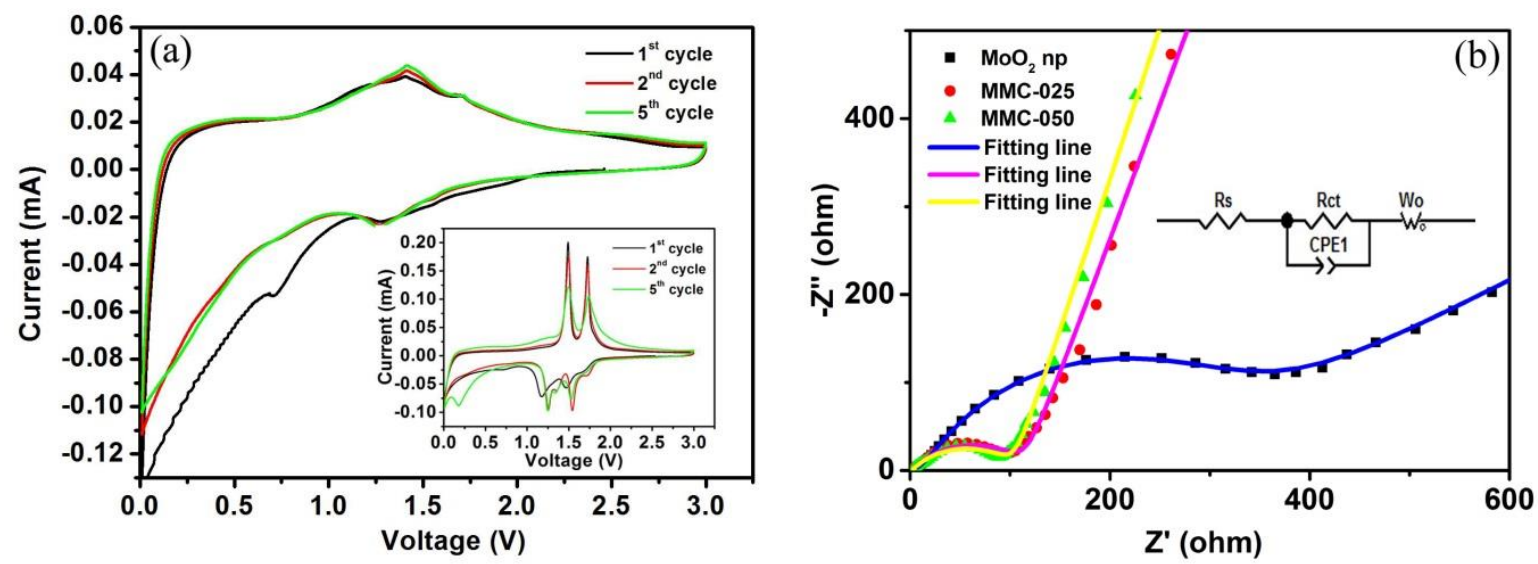

Figure 7. (a) Cyclic voltammograms of MMC-050 at a scan rate of $0.1 \mathrm{mV} \mathrm{s}^{-1}$ for the selected cycles (inset: cyclic voltammograms of $\mathrm{MoO}_{2}$ nanoparticles); (b) electrochemical impedance spectra of MMC-050, MMC-025, and $\mathrm{MoO}_{2} \mathrm{np}$ after 10 charge/discharge cycles. The inset shows the equivalent circuit used for interpreting the spectra. $\mathrm{R}_{\mathrm{s}}$ : electrolyte resistance. $\mathrm{R}_{\mathrm{ct}}$ : charge transfer resistance. $\mathrm{W}_{0}$ : Warburg impedance. CPE1: constant phase element. 


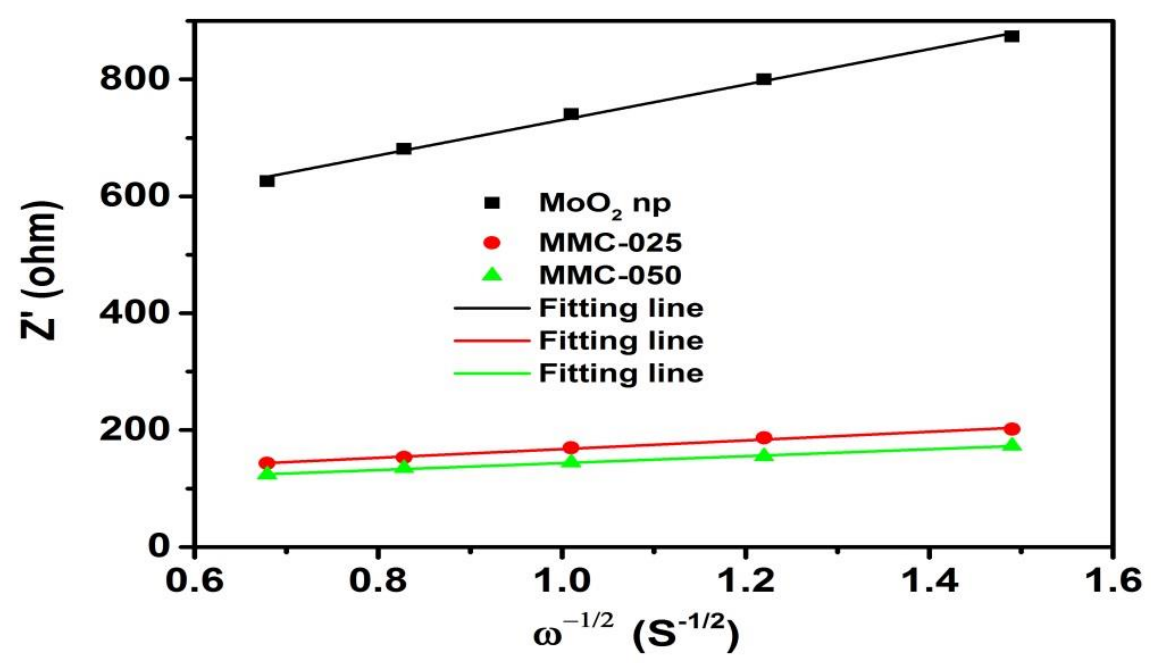

Figure 8. Real part of the complex impedance versus $\omega^{-1 / 2}$ at $25^{\circ} \mathrm{C}$

Electrochemical impedance spectroscopy (EIS) measurements were performed in order to understand the kinetic process. Figure 7(b) shows the Nyquist plots of the MMC050, MMC-025, and $\mathrm{MoO}_{2} \mathrm{np}$ samples after 10 cycles. All plots show a semicircle in the high frequency region related to the charge transfer and ohmic resistances and an inclined line at low frequencies, which is associated with the ion diffusion within the anode. The semicircles for MMC-050 and MMC-025 were smaller than that of $\mathrm{MoO}_{2} \mathrm{np}$, which is reasonable because the $\mathrm{Mo}_{2} \mathrm{C}$ and carbon can promote electron transfer from embedded $\mathrm{MoO}_{2}$ nanoparticles and thus increase conductivity. Also, the unique architecture of the porous spheres facilitates immersion of the porous spheres in the electrolyte, thus shortening the pathways for lithium ion diffusion. The effect of $\mathrm{Mo}_{2} \mathrm{C}$ on the samples can also explained by calculating the lithium diffusion coefficient from EIS data using the following equation

$$
D=R^{2} T^{2} / 2 A^{2} n^{4} F^{4} C^{2} \sigma^{2}
$$


where $D$ is the diffusion coefficient of lithium ions $\left(\mathrm{cm}^{2} \mathrm{~s}^{-1}\right)$ [42]. $R$ is universal gas constant, $T$ means the absolute temperature, $A$ is the area of the cathode $\left(1 \mathrm{~cm}^{2}\right), n$ is the number of electrons involved, $F$ is the Faraday constant, $C$ is the concentration of lithium ions, and $\sigma$ is the Warburg factor, which is related to $Z_{r e} . \sigma$ is obtained from the slope of the lines in Figure 8.

$$
Z_{r e}=R_{l}+R_{c t}+\sigma \omega^{-1 / 2}
$$

The calculated lithium ion diffusion coefficients are $5.89 \times 10^{-19} \mathrm{~cm}^{2} \mathrm{~s}^{-1}, 3.18 \times 10^{-15} \mathrm{~cm}^{2} \mathrm{~s}^{-1}$, and $4.97 \times 10^{-15} \mathrm{~cm}^{2} \mathrm{~s}^{-1}$ for $\mathrm{MoO}_{2} \mathrm{np}, \mathrm{MMC}-025$, and MMC-050, respectively. The diffusion coefficients of MMC-025 and MMC-050 are much higher than the diffusion coefficient of $\mathrm{MoO}_{2} \mathrm{np}$. It is evident that $\mathrm{Mo}_{2} \mathrm{C}$ helps to reduce the charge transfer resistance, which leads to better electronic conductivity and ultimately increases lithium ion diffusion in MMC-025 and MMC-050.

\section{Conclusions}

In summary, we have successfully fabricated $\mathrm{MoO}_{2} / \mathrm{Mo}_{2} \mathrm{C} / \mathrm{C}$ spheres through hydrothermal and calcination processes. After 100 cycles, the discharge capacities of MMC050 and MMC-025 are well maintained at over $800 \mathrm{mAh} \mathrm{g}^{-1}$. The $\mathrm{MoO}_{2} / \mathrm{Mo}_{2} \mathrm{C} /$ carbon sphere samples also demonstrate better rate capability compared to $\mathrm{MoO}_{2}$ nanoparticles, $\mathrm{MoO}_{2} /$ carbon, $\mathrm{MoO}_{2} / \mathrm{Mo}_{2} \mathrm{C}$, and $\mathrm{Mo}_{2} \mathrm{C} / \mathrm{C}$ composites. The structure of these samples with their porous carbon-containing spheres, the good electrical conductivity of carbon and $\mathrm{Mo}_{2} \mathrm{C}$ in the composite, and the buffering effect of carbon can accommodate and alleviate the volume changes throughout the cycling process. The good rate capability performance is generated by three factors: the porous carbon spheres provide short pathways for the transport of electrons and also supply the space for the volume changes of $\mathrm{MoO}_{2}$, the good contact of $\mathrm{MoO}_{2}$ nanoparticles, $\mathrm{Mo}_{2} \mathrm{C}$ nanoparticles, and the carbon in the spheres reduces the electrode 
resistance, thereby facilitating electron movement and also provide short pathways for the transport of electrons, and $\mathrm{Mo}_{2} \mathrm{C}$ with its high specific conductance enhances the electronic conductivity of the spheres and also maintains the structural stability of the spheres during cycling. $\mathrm{MoO}_{2}, \mathrm{Mo}_{2} \mathrm{C}$, and carbon work simultaneously and synergistically, resulting in the superior cycling performance and good rate capability of the $\mathrm{MoO}_{2} / \mathrm{Mo}_{2} \mathrm{C} /$ carbon spheres. By combining the advantages of $\mathrm{MoO}_{2}, \mathrm{Mo}_{2} \mathrm{C}$, and carbon, the $\mathrm{MoO}_{2} / \mathrm{Mo}_{2} \mathrm{C} /$ carbon spheres could be a promising anode material for lithium ion batteries.

\section{Acknowledgements}

Mohammad Ihsan is very grateful for a scholarship from the Australian Development Scholarship scheme of the Australian Government. The authors gratefully acknowledge the use of facilities within the UOW Electron Microscopy Centre and the Wollongong Isotope Geochronology Laboratory. Moreover, the authors also thank Dr. Tania Silver for critical reading of the manuscript and valuable remarks.

\section{REFERENCES}

[1] M.V. Reddy, T. Yu, C.H. Sow, Z.X. Shen, C.T. Lim, G.V. Subba Rao, B.V.R. Chowdari, $\alpha-\mathrm{Fe}_{2} \mathrm{O}_{3}$ nanoflakes as an anode material for Li-ion batteries, Adv. Funct. Mater., 17 (2007) 2792-2799.

[2] X. Zhao, D. Xia, K. Zheng, $\mathrm{Fe}_{3} \mathrm{O}_{4} / \mathrm{Fe} /$ Carbon composite and its application as anode material for lithium-ion batteries, ACS Appl. Mater. Interfaces, 4 (2012) 1350-1356.

[3] G. Zhou, D.-W. Wang, F. Li, L. Zhang, N. Li, Z.-S. Wu, L. Wen, G.Q. Lu, H.-M. Cheng, Graphene-wrapped $\mathrm{Fe}_{3} \mathrm{O}_{4}$ anode material with improved reversible capacity and cyclic stability for lithium ion batteries, Chem. Mater., 22 (2010) 5306-5313.

[4] Y.J. Mai, S.J. Shi, D. Zhang, Y. Lu, C.D. Gu, J.P. Tu, NiO-graphene hybrid as an anode material for lithium ion batteries, J. Power Sources, 204 (2012) 155-161.

[5] H. Zhang, H. Tao, Y. Jiang, Z. Jiao, M. Wu, B. Zhao, Ordered CoO/CMK-3 nanocomposites as the anode materials for lithium-ion batteries, J. Power Sources, 195 (2010) 2950-2955.

[6] N. Du, H. Zhang, B.D. Chen, J.B. Wu, X.Y. Ma, Z.H. Liu, Y.Q. Zhang, D.R. Yang, X.H. Huang, J.P. Tu, Porous $\mathrm{Co}_{3} \mathrm{O}_{4}$ nanotubes derived from $\mathrm{Co}_{4}(\mathrm{CO})_{12}$ clusters on carbon nanotube templates: A highly efficient material for Li-battery applications, Adv. Mater., 19 (2007) 4505-4509. 
[7] L. Zhou, H.B. Wu, Z. Wang, X.W. Lou, Interconnected $\mathrm{MoO}_{2}$ nanocrystals with carbon nanocoating as high-capacity anode materials for lithium-ion batteries, ACS Appl. Mater. Interfaces, 3 (2011) 4853-4857.

[8] Y. Shi, B. Guo, S.A. Corr, Q. Shi, Y.-S. Hu, K.R. Heier, L. Chen, R. Seshadri, G.D. Stucky, Ordered Mesoporous Metallic MoO2 Materials with Highly Reversible Lithium Storage Capacity, Nano Lett., 9 (2009) 4215-4220.

[9] H.-J. Zhang, T.-H. Wu, K.-X. Wang, X.-Y. Wu, X.-T. Chen, Y.-M. Jiang, X. Wei, J.-S. Chen, Uniform hierarchical $\mathrm{MoO}_{2} /$ carbon spheres with high cycling performance for lithium ion batteries, J. Mater. Chem. A, 1 (2013) 12038-12043.

[10] Y. Xu, R. Yi, B. Yuan, X. Wu, M. Dunwell, Q. Lin, L. Fei, S. Deng, P. Andersen, D. Wang, $\mathrm{H}$. Luo, High capacity $\mathrm{MoO}_{2}$ /graphite oxide composite anode for lithium-ion batteries, J. Phys. Chem. Lett., 3 (2012) 309-314.

[11] J.H. Ku, Y.S. Jung, K.T. Lee, C.H. Kim, S.M. Oh, Thermoelectrochemically activated $\mathrm{MoO}_{2}$ powder electrode for lithium secondary batteries, J. Electrochem. Soc., 156 (2009) A688-A693.

[12] P. Poizot, S. Laruelle, S. Grugeon, L. Dupont, J.M. Tarascon, Nano-sized transitionmetal oxides as negative-electrode materials for lithium-ion batteries, Nature, 407 (2000) 496-499.

[13] X.W. Lou, C.M. Li, L.A. Archer, Designed synthesis of coaxial $\mathrm{SnO}_{2} @$ carbon hollow nanospheres for highly reversible lithium storage, Adv. Mater., 21 (2009) 2536-2539.

[14] Z. Wang, J.S. Chen, T. Zhu, S. Madhavi, X.W. Lou, One-pot synthesis of uniform carbon-coated $\mathrm{MoO}_{2}$ nanospheres for high-rate reversible lithium storage, Chem. Commun., 46 (2010) 6906-6908.

[15] L. Ji, Z. Lin, M. Alcoutlabi, X. Zhang, Recent developments in nanostructured anode materials for rechargeable lithium-ion batteries, Energy Environ. Sci., 4 (2011) 2682-2699.

[16] A. Manthiram, C. Tsang, Synthesis of amorphous $\mathrm{MoO}_{2}+\delta$ and its electrode performance in lithium batteries, J. Electrochem. Soc., 143 (1996) L143-L145.

[17] Q. Tang, Z. Shan, L. Wang, X. Qin, $\mathrm{MoO}_{2}$-graphene nanocomposite as anode material for lithium-ion batteries, Electrochim. Acta, 79 (2012) 148-153.

[18] Y. Sun, X. Hu, W. Luo, Y. Huang, Self-assembled hierarchical $\mathrm{MoO}_{2}$ /graphene nanoarchitectures and their application as a high-performance anode material for lithium-ion batteries, ACS Nano, 5 (2011) 7100-7107.

[19] W. Luo, X. Hu, Y. Sun, Y. Huang, Electrospinning of carbon-coated $\mathrm{MoO}_{2}$ nanofibers with enhanced lithium-storage properties, Phys. Chem. Chem. Phys., 13 (2011) 16735-16740. [20] B. Liu, X. Zhao, Y. Tian, D. Zhao, C. Hu, M. Cao, A simple reduction process to synthesize $\mathrm{MoO}_{2} / \mathrm{C}$ composites with cage-like structure for high-performance lithium-ion batteries, Phys. Chem. Chem. Phys., 15 (2013) 8831-8837.

[21] L. Zeng, C. Zheng, C. Deng, X. Ding, M. Wei, $\mathrm{MoO}_{2}$-ordered mesoporous carbon nanocomposite as an anode material for lithium-ion batteries, ACS Appl. Mater. Interfaces, 5 (2013) 2182-2187.

[22] Q. Gao, L. Yang, X. Lu, J. Mao, Y. Zhang, Y. Wu, Y. Tang, Synthesis, characterization and lithium-storage performance of $\mathrm{MoO}_{2} /$ carbon hybrid nanowires, J. Mater. Chem., 20 (2010) 2807-2812.

[23] H.-J. Zhang, K.-X. Wang, X.-Y. Wu, Y.-M. Jiang, Y.-B. Zhai, C. Wang, X. Wei, J.-S. Chen, $\mathrm{MoO}_{2} / \mathrm{Mo}_{2} \mathrm{C}$ heteronanotubes function as high-performance Li-ion battery electrode, Adv. Funct. Mater., 24 (2014) 3399-3404.

[24] H.O. Pierson, Handbook of refractory carbides and nitrides: Properties, characteristics, processing, and applications, Noyes Publications, Park Ridge, N.J, 1996. 
[25] C. Eames, M.S. Islam, Ion Intercalation into Two-Dimensional Transition-Metal Carbides: Global Screening for New High-Capacity Battery Materials, J. Am. Chem. Soc., 136 (2014) 16270-16276.

[26] Q. Gao, X. Zhao, Y. Xiao, D. Zhao, M. Cao, A mild route to mesoporous $\mathrm{Mo}_{2} \mathrm{C}-\mathrm{C}$ hybrid nanospheres for high performance lithium-ion batteries, Nanoscale, 6 (2014) 61516157.

[27] Y. Xiao, L. Zheng, M. Cao, Hybridization and pore engineering for achieving highperformance lithium storage of carbide as anode material, Nano Energy, 12 (2015) 152-160.

[28] Y. Xiao, P. Sun, M. Cao, Core-Shell Bimetallic Carbide Nanoparticles Confined in a Three-Dimensional N-Doped Carbon Conductive Network for Efficient Lithium Storage, ACS Nano, 8 (2014) 7846-7857.

[29] W. Wen, J.-M. Wu, M.-H. Cao, NiO/Ni powders with effective architectures as anode materials in Li-ion batteries, J. Mater. Chem. A, 1 (2013) 3881-3885.

[30] R. Wang, C. Xu, J. Sun, Y. Liu, L. Gao, H. Yao, C. Lin, Heat-induced formation of porous and free-standing MoS2/GS hybrid electrodes for binder-free and ultralong-life lithium ion batteries, Nano Energy, 8 (2014) 183-195.

[31] R. Mukherjee, A.V. Thomas, D. Datta, E. Singh, J. Li, O. Eksik, V.B. Shenoy, N. Koratkar, Defect-induced plating of lithium metal within porous graphene networks, Nat Commun, 5 (2014).

[32] Q. Tang, Z. Zhou, P. Shen, Are MXenes Promising Anode Materials for Li Ion Batteries? Computational Studies on Electronic Properties and Li Storage Capability of Ti3C2 and Ti3C2X2 (X = F, OH) Monolayer, J. Am. Chem. Soc., 134 (2012) 16909-16916. [33] X.W. Lou, J.S. Chen, P. Chen, L.A. Archer, One-Pot Synthesis of Carbon-Coated SnO2 Nanocolloids with Improved Reversible Lithium Storage Properties, Chem. Mater., 21 (2009) 2868-2874.

[34] W.-M. Zhang, J.-S. Hu, Y.-G. Guo, S.-F. Zheng, L.-S. Zhong, W.-G. Song, L.-J. Wan, Tin-Nanoparticles Encapsulated in Elastic Hollow Carbon Spheres for High-Performance Anode Material in Lithium-Ion Batteries, Adv. Mater., 20 (2008) 1160-1165.

[35] M.F. Hassan, Z.P. Guo, Z. Chen, H.K. Liu, Carbon-coated MoO3 nanobelts as anode materials for lithium-ion batteries, J. Power Sources, 195 (2010) 2372-2376.

[36] L. Zhi, Y.-S. Hu, B.E. Hamaoui, X. Wang, I. Lieberwirth, U. Kolb, J. Maier, K. Müllen, Precursor-Controlled Formation of Novel Carbon/Metal and Carbon/Metal Oxide Nanocomposites, Adv. Mater., 20 (2008) 1727-1731.

[37] Y. Sun, X. Hu, J.C. Yu, Q. Li, W. Luo, L. Yuan, W. Zhang, Y. Huang, Morphosynthesis of a hierarchical $\mathrm{MoO}_{2}$ nanoarchitecture as a binder-free anode for lithium-ion batteries, Energy Environ. Sci., 4 (2011) 2870-2877.

[38] Y. Sun, X. Hu, W. Luo, Y. Huang, Ultrafine $\mathrm{MoO}_{2}$ nanoparticles embedded in a carbon matrix as a high-capacity and long-life anode for lithium-ion batteries, J. Mater. Chem., 22 (2012) 425-431.

[39] A. Bhaskar, M. Deepa, T. Narasinga Rao, $\mathrm{MoO}_{2} /$ multiwalled carbon nanotubes (MWCNT) hybrid for use as a Li-ion battery anode, ACS Appl. Mater. Interfaces, 5 (2013) 2555-2566.

[40] A. Chen, C. Li, R. Tang, L. Yin, Y. Qi, $\mathrm{MoO}_{2}$-ordered mesoporous carbon hybrids as anode materials with highly improved rate capability and reversible capacity for lithium-ion battery, Phys. Chem. Chem. Phys., 15 (2013) 13601-13610.

[41] J.J. Auborn, Y.L. Barberio, Lithium intercalation cells without metallic lithium, J. Electrochem. Soc., 134 (1987) 638-641.

[42] Z.-J. Zhang, Q.-Y. Zeng, S.-L. Chou, X.-J. Li, H.-J. Li, K. Ozawa, H.-K. Liu, J.-Z. Wang, Tuning three-dimensional $\mathrm{TiO}_{2}$ nanotube electrode to achieve high utilization of $\mathrm{Ti}$ substrate for lithium storage, Electrochim. Acta, 133 (2014) 570-577. 